\title{
INVESTIGATION OF ARONIA MELANOCARPA FRUIT JUICE FOR SEDATIVE-HYPNOTIC EFFECTS IN RATS
}

\author{
Miroslav Ts. Eftimov, \\ StefkaV. Valcheva-Kuzmanova
}

Department of Pharmacology and Clinical Pharmacology and Therapeutics, Medical University Prof. Dr. Parskev Stoyanov - Varna, Bulgaria

\section{Summary}

Aronia melanocarpa fruit juice (AMFJ) has been intensively studied for effects on the central nervous system. The study aimed to investigate AMFJ for possible sedative-hypnotic effects in rats after acute and subchronic administration. Male Wistar rats were treated orally with three doses of AMFJ $(2.5,5.0$ and $10.0 \mathrm{ml} / \mathrm{kg}$ ) either once (acute treatment) or in 30 days (subchronic treatment). Control rats were similarly treated with distilled water. The tests were performed 1 hour after the last AMFJ administration. The possible sedative-hypnotic effects of the juice were investigated in the open field test (OFT) and thiopental-induced sleeping time test. Substances with sedative-hypnotic effects decrease locomotor activity in the OFT and prolong the time of thiopental-induced sleep. The results from the OFT showed that neither the acute, nor the subchronic treatment of rats with all AMFJ doses affected the horizontal and vertical locomotor activity significantly. The two patterns of administration of AMFJ (acute and subchronic) had no significant effect on the duration of thiopental-induced sleep. The lack of effect of AMFJ on locomotor activity and the lack of prolongation of thiopental-induced sleep showed that AMFJ did not display sedative-hypnotic effects in rats.

Key words: Aronia melanocarpa, locomotor activity, thiopental-induced sleep, rats

\section{Introduction}

Aronia melanocarpa (Michx.) Elliotis a woody shrub of the Rosaceae family, genus Aronia, now commonly planted not only in North America but also in Eastern Europe and Russia. Aronia melanocarpa fruit juice (AMFJ) is an extremely rich source of phenolic phytochemicals such as procyanidins, phenolic acids, and flavonoids, mainly from the subclass of anthocyanins [1].

Many investigations have demonstrated that polyphenols can traverse the blood-brain barrier and can act on the central nervous system (CNS). Anthocyanins from blueberry-fed rats have been found in brain tissue and have been proven to enhance memory [2]. RangelOrdonez et al. [3] detected relatively high concentrations of quercetin, kaempferol and isorhamnetin/tamarixetin in the hippocampus, striatum, and cerebellum of rats.

Received: May 09, 2018

Revision received: June 20, 2018

Accepted: June 26, 2018 
The ${ }^{14} \mathrm{C}$-labeled plant polyphenols found in brain tissue and brain microdialysate indicated that these phytochemicals or their metabolites crossed the blood-brain barrier [4] and accumulated in the brain after a long-term consumption [5].

Sedation is the depression of the awareness to the environment and reduction of responsiveness to external stimulation. Sedative effects have been demonstrated for plant extracts containing polyphenols: flavonoids extracted from Semen Ziziphus jujube [6] and Salvia plebeia extract containing mainly rosmarinic acid [7]. Polyphenolic substances such as flavonoids hesperidin, kaempferol, quercetin and myricetin also possess sedative effects $[8,9]$.

In recent years, it has been found that the polyphenol-rich AMFJ possesses effects on the CNS functions in rats: memory enhancing $[10$, 11], anxiolytic-like $[12,13]$ and antidepressantlike effects [14].

The present study aimed to investigate the possible sedative-hypnotic potential of AMFJ after acute and subchronic administration to rats.

\section{Materials and Methods}

\section{Animals}

The experiments were performed on male Wistar rats $(200 \pm 20 \mathrm{~g})$ housed in plastic cages at $22 \pm 1^{\circ} \mathrm{C}$ and on a standard (12/12) light/dark cycle. The rats had free access to drinking water and food.

Animal treatment and experimental procedures were conducted following the European Union policies and regulations (EU Directive 2010/63/EU for animal experiments).

\section{Experimental substances}

AMFJ was produced from fresh Aronia melanocarpa Elliot fruits. The juice was pasteurized and stored in a refrigerator until the experiment. The phenolic substances in $100 \mathrm{ml}$ AMFJ the were as follows: total phenolics $-546.1 \mathrm{mg}$ gallic acid equivalents, total procyanidins - $312.2 \mathrm{mg}$, cyanidin-3galactoside $-14.4 \mathrm{mg}$, cyanidin-3-arabinoside $6.2 \mathrm{mg}$, cyanidin-3-xyloside - $1.2 \mathrm{mg}$, cyanidin3 -glycoside $-0.4 \mathrm{mg}$, chlorogenic acid -58.5 $\mathrm{mg}$ and neochlorogenic acid - $8.3 \mathrm{mg}$ [15].

Thiopental sodium was purchased from Sandoz GmbH (Austria).

\section{Experimental setting}

Rats $(\mathrm{n}=80)$ were divided into eight groups. The rats were treated orally through an orogastric cannula either once (acute treatment) or in the course of 30 days (subchronic treatment). There were four groups of rats for each experimental period: Control, $\mathrm{AMFJ}_{2.5}, \mathrm{AMFJ}_{5}$, and $\mathrm{AMFJ}_{10}$. These groups were treated respectively with distilled water $(10 \mathrm{ml} / \mathrm{kg})$, AMFJ $2.5 \mathrm{ml} / \mathrm{kg}$ diluted with distilled water to a volume of 10 $\mathrm{ml} / \mathrm{kg}, 5.0 \mathrm{ml} / \mathrm{kg}$ diluted with distilled water to a volume of $10 \mathrm{ml} / \mathrm{kg}$ and $10 \mathrm{ml} / \mathrm{kg}$. The tests were performed 1 hour after the last treatment on the $1^{\text {st }}$ day in the acute experiment and on the $30^{\text {th }}$ day in the subchronic experiment.

\section{Open field test}

The open field test (OFT) is a widely used behavioral method evaluating locomotor activity in both mice and rats [16]. The test was performed for $5 \mathrm{~min}$ in a white painted arena $(100 \times 100 \times 40 \mathrm{~cm})$. The floor was divided into $5 \times 5$ equal size squares. The index for horizontal locomotor activity was the number of crossings (the number of lines crossed by the animal). The index for vertical locomotor activity was the number of rearings (the number of times an animal stood on its hind limbs). The reduced number of crossings and rearings is a measure of CNS depressant activity.

\section{Thiopental sodium-induced sleeping time}

Thiopental sodium-induced sleeping time is a method used to evaluate the sedative effects of the investigated substances [17]. The injection of thiopental sodium to rats (or other animals) leads to loss of their righting reflex and hypnosis.

All animals were injected with thiopental sodium intraperitoneally at a dose of $50 \mathrm{mg} /$ $\mathrm{kg}$ which was dissolved in saline $(1 \mathrm{ml} / \mathrm{kg})$ one hour after conducting the OFT. The duration of sleep was measured as the time interval between the loss and recovery of the righting reflex. Prolongation of the thiopental-induced sleep served as an indicator of a sedative effect.

\section{Statistical analysis}

Results are presented as mean \pm SEM One-way ANOVA and Dunnett's multiple comparison post hoc tests were used to analyze the data. Significance was considered at a level of $\mathrm{p}<0.05$. 
GraphPad Prism statistical software was used for the statistical analysis.

\section{Results}

\section{Open field test}

The results from the OFT after the acute treatment are presented in Figure 1.

The horizontal locomotor activity of the control animals was $55.5 \pm 10.9$. The horizontal activity of AMFJ-treated rats was as follows: $26.1 \pm 5.3,41.8 \pm 8.6$ and $51.3 \pm 8.7$ at the doses of $2.5,5.0$ and $10.0 \mathrm{ml} / \mathrm{kg}$, respectively. The control vertical locomotor activity was $21.0 \pm 2.5$. The vertical movements of AMFJ-treated rats were: $11.0 \pm 2.2$ for the animals treated with $2.5 \mathrm{ml} / \mathrm{kg}$, $17.3 \pm 2.9$ for the animals treated with $5.0 \mathrm{ml} / \mathrm{kg}$ and $22.1 \pm 3.0$ for those treated with $10.0 \mathrm{ml} / \mathrm{kg}$.

The results from the OFT after the subchronic treatment are presented in Figure 2.

In this experiment, the squares crossed by the control animals were $21.2 \pm 5.3$. In rats treated with AMFJ at doses of 2.5, 5.0 and
$10.0 \mathrm{ml} / \mathrm{kg}$, they were $9.7 \pm 2.2,11.7 \pm 2.4$ and $26.4 \pm 6.8$, respectively. The number of rearings of control rats was $11.9 \pm 2.2$. The rearings of rats treated with AMFJ at doses of 2.5, 5.0 and $10.0 \mathrm{ml} / \mathrm{kg}$ were $12.3 \pm 1.7,9.5 \pm 1.6$ and $14.4 \pm 2.5$, respectively.

All these results showed that neither the acute, nor the subchronic treatment with the three AMFJ doses significantly affected the horizontal and vertical locomotor activity of the animals.

\section{Thiopental sodium-induced sleeping time}

The results for the thiopental sodium-induced sleeping time are presented in Figure 3.

In the acute experiment, the duration of hypnosis of control animals was $150.1 \pm 14.8 \mathrm{~min}$. The single pretreatment with AMFJ at doses of $2.5,5.0$ and $10.0 \mathrm{ml} / \mathrm{kg}$ caused shortening of the sleeping time to $121.1 \pm 23.9 \mathrm{~min}, 141.9 \pm 26.2$ $\mathrm{min}$, and $93.3 \pm 12.0 \mathrm{~min}$, respectively, but the effect was not statistically significant.

In the subchronic experiment, the sleeping time of the controls was $113.0 \pm 16.3 \mathrm{~min}$. AMFJ
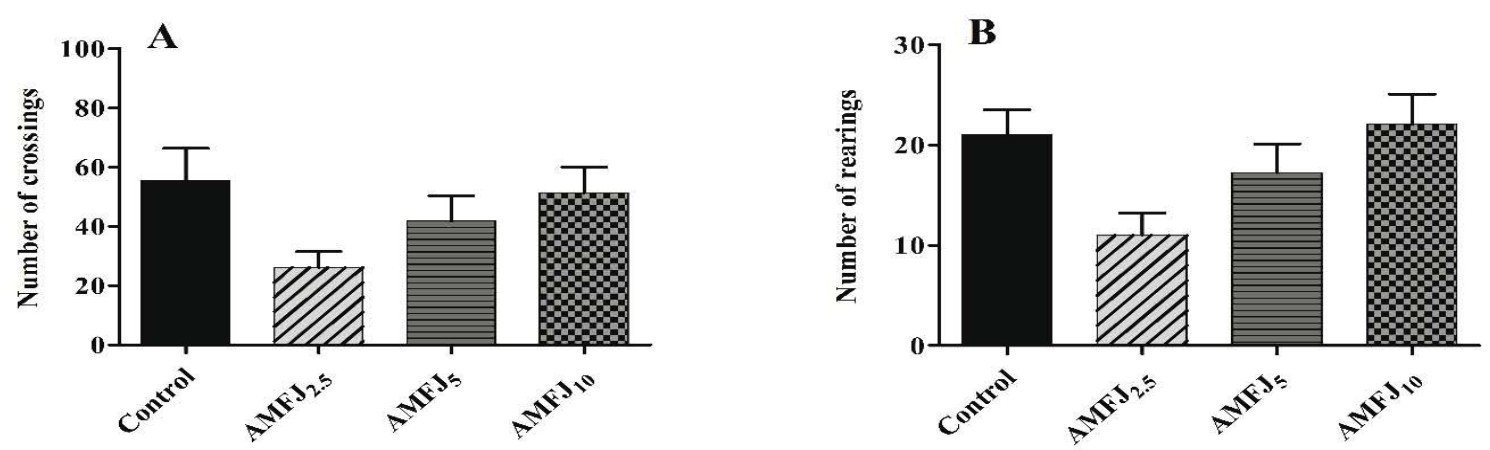

Figure 1. Effect of Aronia melanocarpa fruit juice (AMFJ) as a single dose of 2.5, 5.0 and $10.0 \mathrm{ml} / \mathrm{kg}$ on horizontal (panel A) and vertical (panel B) locomotor activity of rats in OFT.
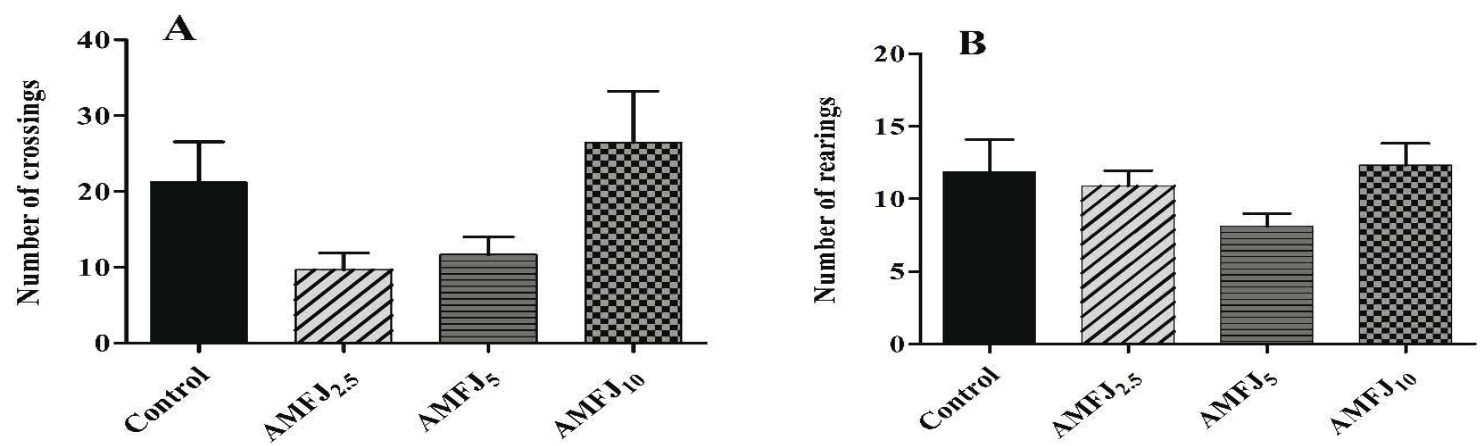

Figure 2. Effect of Aronia melanocarpa fruit juice (AMFJ) administered for 30 days at doses of 2.5, 5.0 and 10.0 $\mathrm{ml} / \mathrm{kg}$ on horizontal (panel A) and vertical (panel B) locomotor activity of rats in OFT. 

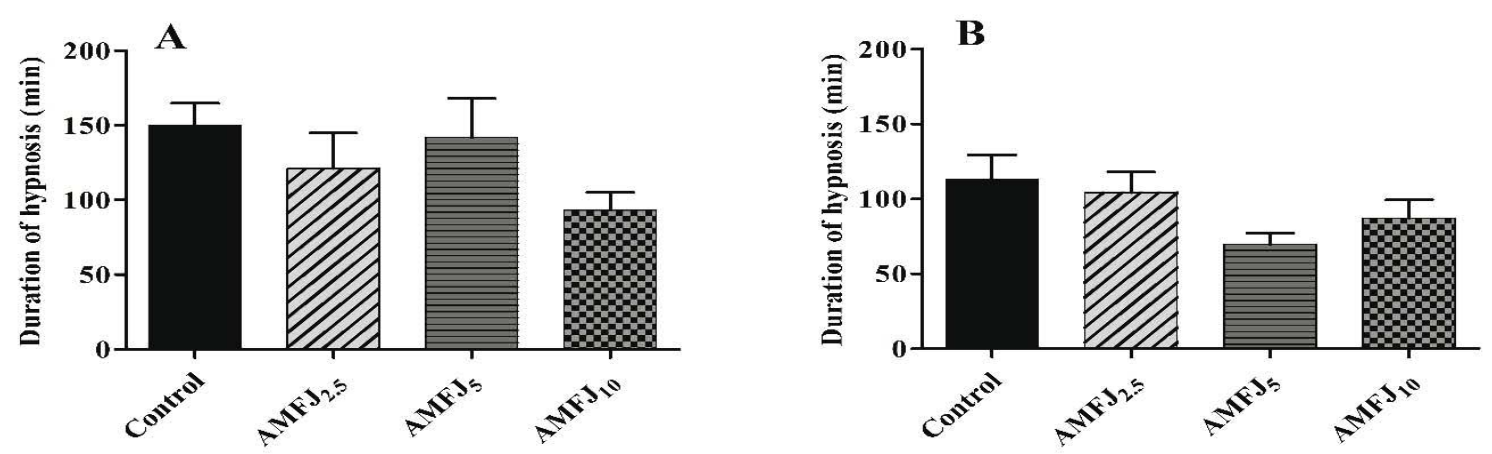

Figure 3. Effect of Aronia melanocarpa fruit juice (AMFJ) on thiopental-induced sleep administered once (panel A) and for 30 days (panel B) at doses of 2.5, 5.0 and $10.0 \mathrm{ml} / \mathrm{kg}$.

treatment resulted in shortening of the duration of hypnosis to $104.2 \pm 13.7 \mathrm{~min}, 69.7 \pm 7.2 \mathrm{~min}$ and $87.2 \pm 12.2 \mathrm{~min}$ for the animals receiving $2.5 \mathrm{ml} / \mathrm{kg}, 5.0 \mathrm{ml} / \mathrm{kg} 10.0 \mathrm{ml} / \mathrm{kg}$ AMFJ doses, respectively, but this shortening was not statistically significant.

\section{Discussion}

The OFT provides information on the locomotor activity of rats and mice. The present study showed that AMFJ administered to rats at doses of $2.5 \mathrm{ml} / \mathrm{kg}, 5.0 \mathrm{ml} / \mathrm{kg}$ and $10.0 \mathrm{ml} / \mathrm{kg}$ either acutely or subchronically for 30 days did not significantly affect the general locomotor activity. These results showed that AMFJ had no CNS depressant effects and did not cause motor discoordination.

Thiopental is a barbiturate, ultrashortacting depressant of the CNS which is used for the induction of anesthesia and short surgical, diagnostic or therapeutic procedures as well. Barbiturates bind to $\mathrm{GABA}_{\mathrm{A}}$ receptor (chloride ion channel) and potentiate inhibitory neurotransmission in the CNS.

The administration with AMFJ to rats did not prolong the thiopental-induced sleeping time duration and even shortened it. These results are in agreement with the results from the OFT, which showed that AMFJ did not decrease the locomotor activity of the rats. The results from both tests demonstrated the lack of a sedativehypnotic effect of AMFJ. Supportive data have shown that chlorogenic acid, an important component of AMFJ, causes mild arousal and prolongs sleep latency in rats [18].

The findings from this study comply with previous investigations with AMFJ which have shown that the acute administration of AMFJ did not significantly affect open field locomotor activity [12]. At the same time, AMFJ had an anxiolytic-like effect [13], which was not accompanied by sedation [12]. The lack of a sedative effect is an excellent advantage of anxiolytic agents. There are data that polyphenolic compounds possess anxiolytic-like effect due to binding affinity to $\mathrm{GABA}_{\mathrm{A}}$ receptors [19-21]. Recent studies have shown that GABA receptors with distinct $\alpha$-subunits are responsible for specific pharmacological effects. Activation of receptors containing $\alpha_{1}$-subunits results in sedative and anticonvulsant actions, while activation of receptors containing $\alpha_{2} / \alpha_{3}$ subtypes produces anxiolytic effect [22]. The absence of a sedative effect of AMFJ demonstrated in this study might be a result of the lack of stimulation of $\alpha 1$-containing GABA receptor.

Another explanation for the shortening of thiopental-induced sleep could be sought in the induction of drug (thiopental) metabolizing enzymes. Thiopental is oxidized by microsomal enzymes mainly in the liver and, to a lesser extent, in the kidney and brain [23]. Further researches are necessary to elucidate the exactly which enzymes involved in the metabolism of thiopental [24]. Bräunlich et al. (2013) [25] have shown that extracts, subfractions, isolated anthocyanins and procyanidins, and phenolic acids from Aronia melanocarpa possess in vitro inhibitory effect on CYP3A4. Inhibition of CYP enzymes could account for a prolongation of the effect of thiopental and consequently of thiopental-induced sleep. In this study, AMFJ did not prolong thiopental-induced sleep in spite 
of a possible CYP inhibition, which further proved the lack of sedative-hypnotic effects of AMFJ.

\section{Conclusions}

The acute and subchronic administration of AMFJ did not cause significant changes in locomotor activity and did not affect the duration of thiopental sodium-induced sleeping time. These results demonstrated that AMFJ did not possess a sedative-hypnotic activity.

\section{Acknowledgements}

The work was not supported by a scientific project.

\section{Conflict of Interest Statement}

The authors declare no conflict of interest.

\section{References}

1. Denev PN, Kratchanov CG, Ciz M, Lojek A, Kratchanova MG. Bioavailability and antioxidant activity of black chokeberry (Aronia melanocarpa) polyphenols: in vitro and in vivo evidences and possible mechanisms of action: a review. Comp Rev Fd Sci Fd Safety. 2012;11:471-89.

2. Andres-Lacueva C,Shukitt-Hale B, Galli RL, Jaurequi O, Lamuela-Raventos RM, Jospeh JA. Anthocyanins in aged blueberry-fed rats are found centrally and may enhance memory. Nutr Neurosci. 2005;8(2):111-20.

3. Rangel-Ordóñez L, Nöldner M, SchubertZsilavecz M, Wurglics M. Plasma levels and distribution of flavonoids in rat brain after single and repeated doses of standardized Ginkgo biloba Extract EGb 761. Planta Med. 2010;76(15):168390.

4. Janle EM, Lila MA, Grannan M, Wood L, Higgins A, Yousef GG, et al. Pharmacokinetics and tissue distribution of ${ }^{14} \mathrm{C}$-labeled grape polyphenols in the periphery and the central nervous system following oral administration. J Med Food. 2010;13(4):926-33.

5. Willis LM, Shukitt-Hale B, Joseph JA. Recent advances in berry supplementation and agerelated cognitive decline. Curr Opin Clin Nutr Metab Care. 2009;12(1):91-4.

6. Jiang JG, Huang XJ, Chen J,Lin QS. Comparison of the sedative and hypnotic effects of flavonoids, saponins, and polysaccharides extracted from Semen Ziziphus jujube. Nat Prod Res. 2007;21(4):310-20.

7. Nugroho A, Kim MH, Choi J, Baek NI, Park HJ. In vivo sedative and gastroprotective activities of Salvia plebeia extract and its composition of polyphenols. Arch Pharm Res. 2012;35(8):140311.

8. Martínez MC, Fernandez SP, Loscalzo LM, Wasowski C, Paladini AC, Marder M, et al. Hesperidin, a flavonoid glycoside with sedative effect, decreases brain pERK1/2 levels in mice. Pharmacol Biochem Behav. 2009;92(2):291-6.

9. Vissiennona C, Nieber K, Kelber O,Butterweck V. Route of administration determines the anxiolytic activity of the flavonols kaempferol, quercetin and myricetin - are they prodrugs? J Nutr Biochem. 2011;23(7):733-40.

10. Valcheva-Kuzmanova SV, Eftimov MT, Tashev RE, Belcheva IP, Belcheva SP. Memory effects of Aronia melanocarpa fruit juice in a passive avoidance test in rats. Folia med. 2014;56(3):199203.

11. Valcheva-Kuzmanova SV, Eftimov MT, Belcheva IP, Tashev RE, Belcheva SP. Effect of Aronia melanocarpa fruit juice on learning and memory in the two-way active avoidance task in rats. $\mathrm{J}$ Biomed Clin Res. 2013; 6(1):18-23.

12. Valcheva-Kuzmanova S, Zhelyazkova-Savova M. Anxiolytic-like effect of Aronia melanocarpa fruit juice in rats. Methods Find Exp Clin Pharmacol. 2009;31(10):651-4.

13. Valcheva-Kuzmanova SV, Eftimov MT, Belcheva IP, Belcheva SP, TashevRE. Anti-anxiety effect of Aronia melanocarpa fruit juice applied subchronically to rats. Farmacia. 2016; 64(3):36771.

14. Eftimov MT, Valcheva-Kuzmanova SV. Antidepressant-like effect of Aronia melanocarpa fruit juice applied subchronically to rats. Scri Sci Med. 2013;45(Suppl. 6):S7-11.

15. Valcheva-Kuzmanova SV, Denev PN, Krachanova MG, Surleva A, Belcheva A. [Composition and antioxidant activity of Aronia melanocarpa fruit juice]. Varna Med Forum. 2014;3(1):15-20. Bulgarian.

16. Gould TD, Dao DT, Kovacsics CE. The Open Field Test. In: Gould T. eds. Mood and Anxiety Related Phenotypes in Mice. New York: Humana Press; 2009. p. 1-20.

17. Turner R. Screening Methods in Pharmacology. 1st ed. New York: Academic Press; 1965.

18. Shinomiya K, Omichi J, Ohnishi R, Ito H, Yoshida T, Kamei C. Effects of chlorogenic acid and its metabolites on the sleep-wakefulness cycle in rats. Eur J Pharmacol. 2004;504(3):185-9.

19. Wang F, Shing M, Huen Y, Tsang SY, Xue H. Neuroactive flavonoids interacting with $\mathrm{GABA}_{\mathrm{A}}$ 
receptor complex. Curr Drug Targets CNS Neurol Disord. 2005;4(5):575-85.

20. Fernandez SP, Nguyen M, Yow TT, Chu C, Johnston GA, Hanrahan JR, et al. The flavonoid glycosides, myricitrin, gossypin and naringin exert anxiolytic action in mice. Neurochem Res. 2009;34(10):1867-75.

21. Jäger AK, Saaby L. Flavonoids and the CNS. Molecules. 2011;16(2):1471-85.

22. Rudolph U, Möhler H. GABA-based therapeutic approaches: GABA $A_{A}$ receptor subtype functions. Curr Opin Pharmacol. 2006;6(1):18-23.
23. Cooper JR, Brodie BB. Enzymatic oxidation of pentobarbital and thiopental. J Pharmacol Exp Ther. 1957;120(1):75-83.

24. Restrepo JG, Garcia-Martín E, Martínez C, Agúndez JA. Polymorphic drug metabolism in anaesthesia. Curr Drug Metab. 2009;10(3):23646.

25. Bräunlich $\mathrm{M}$, Christensen $\mathrm{H}$, Johannesen $\mathrm{S}$, Slimestad R, Wangensteen H, Malterud KE, et al. In vitro inhibition of cytochrome P450 3A4 by Aronia melanocarpa constituents. Planta Med. 2013;79(2):137-41. 